DOI: 10.34015/2523-4552.2021.2.09

УдК 343.851

Гломб Ю. О.,

суддя Рівненського окружного

адміністративного суду,

аспірант Київського університету

права і Національної академії

наук України

ORCID: 0000-0001-8258-1168

\title{
КРИМІНАЛЬНА ВІДПОВІДАЛЬНІСТЬ ЗА НЕДОСТОВІРНІ СТВЕРДЖЕННЯ: ЗАРУБІЖНИЙ ДОСВІД
}

У статті представлено порівняння окремих розділів кримінальних кодексів різних країн щодо відповідальності за недостовірні ствердження. В світовій юрисдикції лжесвідчення вважається серйозним злочином, який призводить до судових помилок оскільки воно може бути використано для узурпації влади суду. Закони штатів та Європи також карають лжесвідчення. Як правило, вибір міри покарання входить до компетенції суддів і може варіюватися від штрафу і виправних робіт до тюремного ув'язнення.

Ключові слова: недостовірні ствердження; лжесвідчення; введення в оману суду або іншого уповноваженого органу; неправдиві показання.

В статье представлено сравнение отдельных разделов уголовных кодексов разных стран относительно ответственности за недостоверные утверждения. В мировой юрисдикции лжесвидетельство считается серьезным преступлением, приводит к судебным ошибкам, поскольку оно может быть использовано для узурпации власти суда. Законы США и Европы также наказывают лжесвидетельство. Как правило, выбор меры наказания входит в компетенцию судей и может варьироваться от штрафа и исправительных работ до тюремного заключения.

Ключевые слова: недостоверные утверждения; лжесвидетельство; введение в заблуждение суд или иной уполномоченный орган; ложные показания.

Постановка проблеми. Сучасна зацікавленість проблемами недостовірних стверджень, зумовлена суспільною небезпекою завідомо неправдивих показань не лише у нашій країні. У всьому світі щоденно допитуються тисячі громадян, адже до сьогодні показання свідків і потерпілих $\epsilon$ найбільш поширеним джерелом доказової інформації. Тому нагальною потребою у підвищенні ефективності органів правосуддя та невідворотності покарання $є$ формування у них активного відношення до своїх обов'язків свідків та усвідомлення відповідальності за недостовірні ствердження.

Аналіз останніх досліджень i публікацій. Важливі питання досліджуваної проблеми розглядалися 
багатьма вітчизняними та зарубіжними вченими. Неправда проявляється на всіх етапах розвитку світової цивілізації та в усіх сферах людської діяльності. Актуальним постає порівняння окремих розділів кримінальних кодексів юрисдикції різних країн щодо відповідальності за недостовірні ствердження.

Постановка завдання. Виходячи 3 цих міркувань, мета статті полягає в тому, щоб дослідити кримінальну відповідальність за недостовірні ствердження в зарубіжних країнах.

Виклад основного матеріалу В світовій юрисдикції лжесвідчення вважається серйозним злочином, який призводить до судових помилок оскільки воно може бути використано для узурпації влади суду Закони штатів та Європи також карають лжесвідчення. У США лжесвідчення карається строком до 5 років в федеральних судах [1]. Як правило, вибір міри покарання входить до компетенції суддів і може варіюватися від штрафу і виправних робіт до тюремного ув'язнення, в залежності від місцевих законів і обставин конкретного випадку. У Швейцарії лжесвідчення карається тюремним ув'язненням від 6 місяців до 5 років, в Ізраїлі - строком до 7 років, в Німеччині - до 5 років (стаття 154 КК Нiмеччини), у Великобританії - до 7 років [2].

Так, стаття 154 Кримінального кодексу Німеччини має назву «Лжесвідчення» (Meineid). Частина 1 наголошує, що будь-який, хто хибно лається перед судом або іншим органом, відповідальним за принесення присяги, буде покараний позбавленням волі на строк не менше одного року. Але частиною 2 передбачено, що, у менш серйозних випадках лжесвідчення карається позбавленням волі на строк від шести місяців до п'яти років [3].

Лжесвідчення (клятвопорушення), в світовому розумінні, це злочин, що виражається в свідомої дачі завідомо неправдивої інформації правоохоронним органам, суду або органам влади. Часто відбувається в формі дачі неправдивих свідчень свідком або обвинуваченим на суді або під час слідства, а також посадовою особою під присягою.

Під лжесвідченням потрібно розуміти умисну дію неправдивої присяги або фальсифікації заяви про правду, в усній або письмовій формі, щодо питань, які мають значення для офіційного розгляду. Цікавим виглядає той факт, що у деяких світових юрисдикціях, не вважається злочином помилкова заява (навмисно або ненавмисно) зроблена під присягою (брехня про свій вік). Вважається, що кримінальна відповідальність настає лише в той момент, коли заявник помилково стверджує істинність заяв (зроблених або очікуваних), які мають значення для результату судового розгляду (брехня про свій вік, коли вік є фактом, що впливає на юридичний результат [4].

У деяких країнах лжесвідчення кваліфікують як: 1) кримінальний злочин (наприклад, Загальний закон США відповідно до федерального закону кваліфікує лжесвідчення як кримінальний злочин і передбачає тюремне ув'язнення терміном до п'яти років); 2) як правопорушення, у випадках, що викликають протиправне виконання (причиною неправомірного страти іншої особи або переслідування за заподіяння неправомірного страти іншій особі), зок- 
рема Кримінальний кодекс Каліфорнії; 3) як вбивство або замах на вбивство в країнах, де зберігається смертна кара (тому карається стратою). Лжесвідчення вважається кримінальним злочином в більшості штатів США, а також в більшості штатів Австралії. Так, у Квінсленді лжесвідчення карається позбавленням волі на строк до довічного ув'язнення, якщо воно вчинене 3 метою привернути невинну людину до злочину, покараному довічним тюремним ув'язненням (згідно з розділом 124 Закону Кримінального кодексу Квінсленда 1899 року).

У деяких країнах, таких як Франція і Італія, підозрюваних не можна вислухати під присягою або підтвердженням, і тому вони не можуть давати неправдиві свідчення, незалежно від того, що вони говорять під час суду.

У Сполучених штатах застосовуються правила про лжесвідчення. Якщо особа зробила заяву під страхом покарання за лжесвідчення, навіть якщо ця особа не була приведена до присяги і не було підтверджено в якості свідка перед відповідною посадовою особою (декларація про прибутковий податок в США, яка за законом повинна бути підписана як вірна і правильна під страхом покарання за лжесвідчення (26 U.S. Code $\S$ 6065)). Федеральний податковий закон США передбачає кримінальне покарання до трьох років позбавлення волі за порушення закону про податкову декларацію про лжесвідчення. (26 U.S. Code $§ 7206$ (1)).

Не $є$ лжесвідченням заяви, які тягнуть за собою інтерпретацію фактів (невірні висновки мимоволі, чесні помилки без наміру обдурити, хибні уявлення про певні факти, неточні спогади, мати інше сприйняття того, як правильно викладати правду), та твердження, які $є$ фактами несуттєвими для судового розгляду (упущення тощо). Як і більшість інших злочинів в системі загального світового права, для того, щоб бути визнаним винним у лжесвідченні, людина повинна мати намір (mens rea) вчинити дію і фактично зробити це (actus reus).

Також у деяких інших англомовних країнах Співдружності націй, (Сполучених Штатах, Кенії, Шотландії) підбурювання до дачі неправдивих показань, намагання спонукати іншу людину лжесвідчити, саме по собі є злочином.

Сполучене Королівство Англія і Уельс розуміють під лжесвідченням правопорушення, встановлене законом в Англії та Уельсі. Склад злочину лжесвідчення може вважається готуванням заяви, або істинною або брехнею, даною під присягою в судовому порядку, при якому особа знає про неправильність або вважає, що це брехня. Особа, засуджена за лжесвідчення, підлягає покаранню у вигляді позбавлення волі на строк до семи років або штрафу, або і того, i іншого. Відповідно до Закону про лжесвідчення 1911 року особа, винна у вчиненні правопорушення відповідно до розділу 11 (1) Закону про Європейські співтовариства 1972 (Лжесвідчення в Суді Європейського Союзу), може бути притягнута до кримінальної відповідальності і покарана в Англії і Уельсі як злочин по розділу 1 (1 Perjury 1), a саме, «якщо будь-яка особа, законно присягнула як свідок або як перекладач у судовому процеci, навмисно робить у цьому процесі матеріали висловлювання, які, на iㅣ думку, є неправдивими або не вважає 
істинними, вона буде винною в неправдивих свідченнях, і після засудження за обвинувальним висновком підлягає покаранню до покарання на строк, що не перевищує семи років, або позбавленню волі на строк, що не перевищує двох років, або до штрафу, або до такої покарання, або позбавлення волі та штрафу». «Судовий розгляд» включає розгляд в будь-якому суді, трибуналі або при особі, що має за законом право заслуховувати, отримувати й досліджувати докази під присягою (1 Perjury 2, 3). Тобто, всі покази розглядаються як зроблені в ході судового розгляду. Заява, зроблена під присягою свідком за межами Сполученого Королівства і дане в якості свідків у публічно відповідно до розділу 32 Закону про кримінальне правосуддя 1988 року, має розглядатися розділом 1 як зроблена в ході розгляду, в ході якого це дано в якості доказу. Заява, зроблена особою, для цілей судового розгляду, $є$ законною як: 1) в Англії, так в іншій частині володінь 2) у британському суді, законно заснованому в будь-якому місці на море або суші за межами володінь; 3) в суді будь-якого іноземної держави (1 Perjury 4). Пункт 6 Розділу 1 Закону підкреслює, що питання про те, чи була суттєвою заява, за якою обвинуваченого у лжесвідченні, $€$ питанням закону, який повинен вирішуватися судом першої інстанції. Розділ 1 застосовується щодо особи, яка виконує функції посередника, як він застосовується по відношенню до особи, законно приведеного до присяги в якості перекладача в судовому розгляд [5].

Лжесвідчення (неправдиві свідчення) $€$ злочином відповідно до ст. 117 Кримінального кодексу, який застосовується як в північних та південних штатах Нігерії. Будь-яка особа, яка в будь-якому судовому розгляді, або 3 метою відкриття будьякого судового розгляду, свідомо дає неправдиві свідчення, торкаючись будь-яких питань, які $є$ матеріалом для будь-якого питання, які мають значення то в залежності в рамках цього провадження, або мало намір підняти в рамках цього провадження, $є$ винним злочин, яке називається лжесвідчення. В Кримінальному кодексі Нігерії не має значення: 1) чи ці показання дані під присягою чи під будь-яким іншим уповноваженого законом органом; 2) чи застосована фактично особлива форми і церемонія (в управлінні присягою) бо для особи, що дає показання, щоб говорити правду це несуттєво; 3) чи в усній або в письмовій формі дані неправдиві свідчення; 4) чи утворений або утримується суд або трибунал в потрібному місці, якщо він насправді діє в якості суду в якому даються показання; 5) чи є людина, яка дає показання компетентним свідком чи ні, чи є свідоцтво допустиме в ході провадження чи ні. Як кримінальний злочин трактується говорити брехню як в ході судового розгляду так й поза судовим розглядом. Але, згідно розділу 119 Кримінального кодексу Нігерії, особу не може бути визнано винним у вчиненні лжесвідчення на непідтверджених свідченнях одного свідка. Лжесвідчення має бути доведено або підтвердженим з двома свідками, або по одному свідкові з підтвердженням інших матеріалів і відповідних фактів по суті, які підтверджують його показання. Розділ 118 Кримінального кодексу транслює, що будь-яка особа, яка вчиняє лжесвідчення карається позбавленням 
волі на 14 років. Якщо злочинець скоює злочин, при якому засудження іншої людини за злочин, який карається смертю або довічним позбавленням волі, він несе відповідальність у вигляді позбавлення волі довічно. Таким чином, відповідно до Кримінального кодексу, де $\epsilon$ відповідальність за вчинення навмисної дії давання неправдивих свідчень, має бути встановлено, чи зроблено це навмисно, чи з необережності чи помилково [6].

Правова система Об'єднаних Арабських Еміратів (Legal system of the United Arab Emirates) під хибними ствердженнями розуміє злочини, за які засуджуть особу (за неправдиві звинувачення, за надання неправдивих свідчень).

Законодавство Канади вважає це злочином проти відправлення закону і правосуддя, що вводить в оману правосуддя (PART IV Offences Against the Administration of Law and Justice (continued) Corruption and Disobedience (continued). Розділ 131 «Лжесвідчення» Perjury (1) Відповідно до підрозділу (3), кожен робить лжесвідчення, яке з наміром ввести в оману робить перед особою, уповноваженою законом, яка дозволяє зробити це перед ним, неправдиву заяву під присягою або урочистим підтвердженням під присягою, урочисту заяву або свідчення або усно, знаючи, що заява $\epsilon$ неправдивою. (1.1) Відповідно до підрозділу (3), кожна особа, яка дає показання відповідно до підрозділу 46 (2) Канадського Закону про докази або дає свідчення або заяву відповідно до наказу, прийнятого згідно з розділом 22.2 Закону про взаємну правову допомогу у кримінальних справах, здійснює лжесвідчення, який з наміром ввести в оману робить неправдиву заяву, знаючи, що вона неправдива, незалежно від того, чи було це неправдива заява зроблена під присягою або урочистим підтвердженням відповідно до підрозділу (1), за умови, що неправдиву заяву було зроблено в дотримання будь-яких формальностей, необхідних законом місця за межами Канади, в якому особа фактично присутня або чути. (2) Підрозділ (1) застосовується незалежно від того, чи зроблено заяву, згадану в цьому підрозділі, в ході судового розгляду. (3) Підрозділи (1) і (1.1) не застосовуються до заяви, згаданій в будь-якому 3 цих підрозділів, яка зроблено особою, яка не має спеціального дозволу, не уповноважена або не потрібно за законом робити таку заяву. Злочин про дачу лжесвідчення кваліфікується статтею 132 Кримінального кодексу Канади. Кожен, хто дає неправдиві свідчення, винен в кримінальному злочині і підлягає позбавленню волі на строк до чотирнадцяти років. Відповідно статті 133 жодна особа не може бути засуджена за злочин, передбачений статтею 132, на підставі показань тільки одного свідка, якщо показання цього свідка не підкріплені конкретними матеріалами, що свідчать про причетність обвинуваченого [7].

Так, особа, яка перед Судом $\epsilon_{\mathrm{B}}$ ропейського Союзу присягається в чому-небудь, що, як вона знає, є неправдивим або не вважає правдою, незалежно від його національності, винне в лжесвідченні. Судовий розгляд по даному правопорушенню може бути розпочато в будь-якому місці штату, і правопорушення може у всіх випадкових цілях розглядатися як вчинене в цьому місці. 
Кримінальний кодекс Індії Главою ХІ Розділами з 191 по 229 «Про неправдиві свідчення і злочини проти громадського правосуддя» кваліфікує це як злочин. Вважається, що історичний досвід Індії в пошуку власної концепції покарання $\epsilon$ унікальним. Значний вплив на це справило колоніальне минуле та англосаксонська правова культура, а також філософсько-релігійні, етніко-лінгвістичні, кастово-племінні й інші загальнокультурні чинники. У Кримінальному кодекci (Indian Penal Code) 1860 р. склалася оригінальна пенологічна конструкція і система покарань, чому сприяли історико-теоретичні передумови, кримінальна політика британської Індії та її постколоніальний розвиток. Сучасна Індія має суперечливий досвід пошуку ефективних кримінопенологічних теорій, який суттєво доповнює класичну (вестернізованих) кримінологію. Історично сформовані в країнах «глобального півдня», в тому числі в Індії, особливі концепції i практики покарання сьогодні пильно вивчаються в рамках такого нового напряму, як «південна кримінологія» (Southern Criminology) [8].

Висновки. Процес еволюції кримінальної відповідальності за оману призвів до формування в більшості держав систематизованих за інститутами кримінального права нормативно-правових актів - кодексів (уложень, зведень тощо) з відповідними статтями.

Орієнтація України на розбудову правової держави та впровадження загальноєвропейських цінностей актуалізують дослідження юридичної відповідальності держави перед громадянином і особи перед суспільством. У світлі євроінтеграційних прагнень України з-поміж пріоритетних завдань -реформування судової системи, яка передусім має на меті вирішити питання незалежності судової влади та імплементації нового законодавства у відповідних сферах, а також розв'язати проблеми, пов'язані з підвищенням рівня соціальної відповідальності.

\section{Список використаних джерел}

1. Criminal Law: Witnesses FAQ. Архівна копія від 25 березня 2010 на Wayback Machine.

2. Revised Statute from The UK Statute Law Database. Архивная копия от 9 сентября 2010 на Wayback Machine.

3. Strafgesetzbuch (StGB) $§$ 154 Meineid. URL:http://www.gesetze-iminternet.de/stgb/_154.html

4. Perjury. URL: https://en.wikipedia.org/wiki/Perjury

5. UK Public General Acts 1911 (Regnal. 1_and_2_Geo_5). Table of contents. URL: https://www.legislation.gov.uk/ukpga/Geo5/1-2/6/section/1

6. Perjury in Nigeria. URL: https://en.wikipedia.org/wiki/Perjury_in_Nigeria

7. Кримінальний кодекс. Міністерство юстиції Канади. Criminal Code 1985. URL: https://laws-lois.justice.gc.ca/eng/acts/C-46/page-32.html\#h-117964

8. Крашенинникова Н. А. Трикоз Е. Н. Институт наказания в Уголовном кодексе Индии 1860 года: пенологические теории. Всероссийский криминологический журнал. 2018. T. 12, № 3. C. 431-443. DOI: 10.17150/2500-4255.2018.12(3)

\section{References}

Krasheninnikova N.A., Trikoz E.N. Institute of punishment in the Indian Penal Code of 1860: the penological theories. Vserossiiskii kriminologicheskii zhurnal = Russian Journal of 
Criminology, 2018, vol. 12, no. 3, pp. 431-443. DOI: 10.17150/2500-4255.2018.12(3).431443. [in Russian].

Y. Glomb, Judge of Rivne District Administrative Court, Postgraduate Student of Kyiv University of Law and National Academy of Sciences of Ukraine

ORCID: 0000-0001-8258-1168

\section{Criminal liability for Perjury: international experience}

The current interest in the problems of unreliable allegations is due to the public danger of knowingly false testimony not only in our country. Thousands of citizens are interrogated every day around the world, because to this day the testimony of witnesses and victims is the most common source of evidence. Therefore, the urgent need to increase the efficiency of the judiciary and the inevitability of punishment is to form in them an active attitude to their responsibilities as witnesses and awareness of responsibility for false allegations.

The article presents a comparison of individual sections of the criminal codes of different countries regarding liability for inaccurate statements. In world jurisdiction, perjury is considered a serious crime, leads to miscarriages of justice as it can be used to usurp the authority of the court. State and European laws also punish perjury. In general, the choice of the punishment is within the competence of judges and can range from a fine and correctional labor to imprisonment, depending on local laws and the circumstances of the particular case. In Switzerland, perjury is punishable by imprisonment from 6 months to 5 years, in Israel - for up to 7 years, in the USA - up to 5 years, in Germany - up to 5 years, in Great Britain - up to 7 years.

False testimony (perjury), in the global sense, is a crime that is expressed in the deliberate giving of knowingly false information to law enforcement agencies, courts or authorities. It often takes the form of giving false testimony by a witness or accused in court or during an investigation, as well as by an official under oath.

False testimony is to be understood as the intentional act of a false oath or falsification of a statement of truth, orally or in writing, on matters relevant to formal proceedings. Interesting is the fact that in some world jurisdictions, a false statement (intentionally or unintentionally) made under oath (a lie about one's age) is not considered a crime. Criminal liability is considered to arise only when the applicant erroneously asserts the truth of the statements (made or expected) that are relevant to the outcome of the trial (lying about his age, when age is a fact that affects the legal outcome.

The process of evolution of criminal liability for deception has led to the formation in most states of systematized by the institutions of criminal law regulations - codes (agreements, summaries, etc.) with relevant articles.

Keywords: false statements; perjury; misleading a court or other authorized body; false testimony. 